\title{
An institutional view on access to finance by Tanzanian women owned enterprises
}

\author{
Vanessa K. Naegels ${ }^{*}$, Neema Mori** \& Bert D'Espallier ${ }^{* * *}$

\begin{abstract}
Note that this is the open-access version of the paper. The final version of the paper is forthcoming in:
\end{abstract}

\section{Venture Capital: An International Journal of Entrepreneurial Finance}

\begin{abstract}
We investigate the limited use of bank and microfinance loans by Tanzanian female entrepreneurs. Using survey data, we observe that female entrepreneurs mainly use informal sources to finance their businesses. We analyse how 'perceptions' of gendered cognitive and normative institutions determine whether a female entrepreneur applies for a formal loan. Following results stand out: first, we find that high collateral requirements, interest rates and personal guarantee requirements make formal loans unattractive. Second, female entrepreneurs only apply when they expect to be successful. Since they 'perceive' access to finance to be more problematic for women, female entrepreneurs are discouraged from applying. Third, female entrepreneurs 'perceive' they have insufficient access to financial knowledge which again will prevents them from applying. This study contributes to theory by exploring the effect of entrepreneurs' perceptions of the institutional business environment on financing behaviour. Furthermore, we show that the low use of formal loans by female entrepreneurs is primarily demand-driven, which calls into question the effectivity of policy recommendations aiming to increase supply of formal loans.
\end{abstract}

Keywords: Development economics, Finance, Tanzania, Women owned businesses, Institutional Theory, Debt

\footnotetext{
* KU Leuven, Belgium; ** University of Dar es Salaam, Tanzania; *** KU Leuven, Belgium, corresponding author
} 


\section{Introduction}

Entrepreneurs are influenced by and interact with their environment. Consequently, entrepreneurship research increasingly adopts an institutional viewpoint. Institutional theory states that individuals are influenced by regulatory, normative and cognitive institutions which determine appropriate behavior and grant entrepreneurs legitimacy (Scott, 2001). Previous research shows significant institutional voids in emerging economies and economies in transition creating important barriers to entrepreneurship. In short the business environment in economies in transition or emerging economies is "hostile in social, economic and political terms" (Smallbone \& Welter, 2001 p 260-261). Specifically, legal and financing institutions are inefficient and the political framework is unstable (Scheela et al, 2015; Peng, 2002). Businesses are subject to long administrative procedures, corruption and extremely high taxes (Amine \& Staub, 2009). This leads to a larger informal economy, smaller businesses and more reliance on informal institutions like networks and trust (Smallbone \& Welter, 2001).

Female entrepreneurs are more disadvantaged by institutional voids than male entrepreneurs because it is harder for them to deal with the consequences of ineffective formal institutions (Amine \& Staub, 2009). Furthermore, gendered informal institutions both cultivate a negative societal view on female entrepreneurship and lead to a traditional role reserved for women in the economy (Welter \& Smallbone, 2008; Pathak, Golz \& Buche, 2013).

One of the most important consequences of inefficient institutions is the lack of small business finance. Insufficient access to finance is the largest constraint to business growth for female entrepreneurs in Tanzania (ILO, 2014). Consequently, the research questions we aim to answer are the following: a. what are the most important problems Tanzanian female entrepreneurs experience when accessing bank and microfinance loans? and b. how are these problems embedded in the institutional framework?

Previous research finds that institutional voids lead to underdeveloped capital markets, more asymmetric information between lenders and borrowers and higher credit risk (Peng \& Heath, 1996; Hainz, 2003; Khanna \& Palepu, 1997). This leads to unattractive borrowing terms for 
formal loans (Menkhoff et al, 2006). However these studies mostly rely on quantitative international databases to investigate the influence of institutions on national entrepreneurship rates. Consequently, these studies mostly create basic insights on a national level, not on the level of individual businesses or entrepreneurs. Another strand of literature investigates financing problems individual entrepreneurs face and links it to entrepreneurial and business characteristics. This strand of literature does not take into account the environmental and institutional influence.

We argue that entrepreneurs' perceptions of institutions and not the institutions themselves may drive financing behavior. We aim to contribute to literature on institutional theory and small business financing in emerging economies by exploring how entrepreneurs' perceptions of gendered normative and cognitive institutions influence demand for formal loans. With its high economic growth but less developed institutional framework, Tanzania is an interesting context to study this relationship. First we map the financing mix of Tanzanian female entrepreneurs. From this we deduce the main problems they face namely access to bank and microfinance loans. We find that this is primarily caused by a lack of loan applications. We then explore how female entrepreneurs' perceptions of borrowing terms, gender inequality in access to finance and, access to financing knowledge influence whether or not entrepreneurs apply for formal loans. We also investigate which entrepreneurs report most problems with respect to borrowing terms when accessing formal loans.

Our paper is structured in the following way. The literature review presents the current state of the literature as well as how our study contributes to it. This is followed by a methodology section and the results of our analyses. The implications of our research are reviewed in the discussion and conclusion section. 


\section{Literature review}

\section{Institutional theory and entrepreneurship}

Corporate behavior and strategies are influenced by the institutions companies are subjected to (Peng, 2002). These consist of written and unwritten rules which define appropriate behavior (North, 1990). This institutional influence has three dimensions. The regulatory pillar consists of formal laws and rules that actors need to follow in order to avoid punishment. The normative influence concerns informal norms and values, often originating from culture. The cognitive pillar consists of an individual's personal understanding of his environment and self-imposed limitations about possible actions and strategies (Scott, 2001; Hoffman, 1999; Baugh, Chua \& Neupert, 2006). Rates of entrepreneurial activity vary between countries, and entrepreneurs operate in interaction with their environment. As a result it is tedious to study entrepreneurship independent from its context (Pathak, Golz \& Buche, 2013). Institutions influence "entrepreneurial attitudes and motives, the resources that can be mobilized, as well as the constraints on and opportunities on/for starting and running a business" (Welter \& Smallbone, 2011, p. 108). Consequently, institutional theory is being used more and more often as a framework to research company behavior (Welter \& Smallbone, 2011).

Previous research shows that formal institutions influence the relative costs and benefits of starting and running a business (as compared to those of traditional employment) (Pathak, Golz \& Buche, 2013). More specifically, a stable regulatory environment facilitating access to resources and with adequate rule enforcement stimulates entrepreneurship. Lengthy procedures, inadequate property laws, high levels of taxation and high unemployment benefits however increase the opportunity cost which makes entrepreneurship less attractive (Yousafzai, Saeed \& Muffatto, 2015; Estrin \& Mickiewicz, 2011). Informal institutions influence the feasibility and desirability of being an entrepreneur (Pathak, Golz \& Buche, 2013). Normative institutions in particular, influence the social acceptability and image of entrepreneurs in society (Yousafzai, Saeed \& Muffatto, 2015). Finally, cognitive institutions influence the perception of individuals of their ability to run a business (Yousafzai, Saeed \& Muffatto, 2015). 
It has been proven that individuals with higher levels of self-efficacy are more likely to start a business (Pathak, Golz \& Buche, 2013). Cognitive institutions also influence the dispersion of skills needed to start a business (Busenitz, Gómez \& Spencer, 2000). In our study, we focus on perceptions of normative and cognitive institutions and investigate how these perceptions influence individual financing behavior.

\section{Institutions in emerging economies}

In emerging economies, entrepreneurship plays an important role. Subsistence entrepreneurs are pushed into entrepreneurship where they can earn a basic income. Innovative entrepreneurs are pulled into entrepreneurship by new business opportunities that arise from a developing market (Smallbone \& Welter, 2001; Baughn, Chua \& Neupert, 2006). Institutional theory is a particularly appropriate framework when researching entrepreneurship in emerging economies because its businesses are more strongly influenced by institutions (Hoskisson et al, 2000; Welter \& Smallbone, 2008). Furthermore, the business environment in economies in transition or emerging economies appears to be "hostile in social, economic and political terms" (Smallbone \& Welter, 2001 p260-261). Previous research shows that the political framework can be unstable (Peng, 2002) and that legal and financial institutions are often inefficient in emerging countries (Scheela et al, 2015). Formalization procedures are extremely long and complex resulting in a large informal economy and a high incidence of corruption (Amine \& Staub, 2009). Even more businesses are driven into informality by excessive taxation and unpredictable government officials (Smallbone \& Welter, 2001). Additionally, rule enforcement mechanisms are weak or absent (Welter \& Smallbone, 2011).

These institutional deficiencies cause uncertainty and high costs constraining business startups and growth (Peng \& Heath, 1996; Acs \& Autio, 2010). Consequently, in many emerging economies informal institutions substitute formal institutions. Personal trust and networks reduce risks and transaction costs in unstable environments and ensure contracts are enforced (Smallbone \& Welter, 2001). Networks also help to interpret regulations and avoid harassment and corruption (Peng \& Heath, 1996; Peng, 2001). 
Another important consequence of institutional voids is the lack of capital for small businesses (Hitt et al, 2004). A lack of investor protection leads to underdeveloped capital markets (La Porta et al, 1997; 2000; Peng \& Heath, 1996). Furthermore, inefficient judicial systems cause financiers to be more reluctant to lend out money because they cannot count on the judiciary power to intervene (Khanna \& Palepu, 1997). Also, a high degree of information asymmetry between credit providers and entrepreneurs leads to high collateral requirements (Hainz, 2003). On top of that, weak property rights and the lack of enforcement mechanisms means entrepreneurs often cannot use their assets as collateral (Estrin \& Mickiewicz, 2011). Loan terms are made even less attractive by a lack of competition between banks which leads to rent extraction (Menkhoff et al., 2006). Finally, complex formalization procedures and high tax rates cause small businesses to remain informal further limiting financing opportunities (Smallbone \& Welter, 2001; Aga \& Reilly, 2011).

Entrepreneurs in emerging economies use informal institutions to alleviate the financing gap resulting from inefficient formal institutions. According to Peng and Heath (1996), growth through networks is the dominant strategy in emerging countries because organizations cannot obtain the necessary resources to grow either internally or through mergers and acquisitions. Instead entrepreneurs rely on their personal networks as a method of financial bootstrapping. Small business owners who cannot access formal loans borrow from family, friends or other informal sources. Not all entrepreneurs have access to networks or mechanisms of personal trust. Especially smaller or informal business most likely have to follow different strategies like for example bribery (Welter \& Smallbone, 2011). Another coping strategy employed is serial entrepreneurship. Since a lack of formal finance prevents businesses from growing, entrepreneurs run multiple small businesses to ensure sufficient income. Revenue from the different businesses is later used to start a more substantial enterprise (Smallbone \& Welter, 2001). 


\section{Institutions and female entrepreneurship}

Female entrepreneurs encounter different institutional forces than male entrepreneurs. This results in different rates of male- and female entrepreneurship. Just like male entrepreneurs, some women go into entrepreneurship to take advantage of new opportunities. However, in emerging economies, traditional pull factors leading to innovative entrepreneurship disadvantage women. Whether an individual starts a business depends on his or her degree of self-efficacy (confidence in your abilities to succeed as an entrepreneur) and fear of failure. However in emerging economies, where there is low female participation to the economy (or low opportunity to participate) and/or low female educational attainment, even women who are confident in their abilities to successfully run a business might be discouraged to do so (Pathak, Golz \& Buche, 2013; Baughn \& Neupert, 2006). Furthermore, in emerging economies the profession of entrepreneur is associated with men and masculine characteristics (Baughn \& Neupert, 2006). Similarly, Amine and Staub (2009) find that although entrepreneurship is regarded favorably in Sub-Saharan Africa, female entrepreneurship is frowned upon. This could potentially dissuade otherwise motivated women from starting a business (Welter \& Smallbone, 2008).

Given the hazardous environment they face it is rather surprising that so many women in emerging economies still start businesses. However female access to the labor market is constrained. Consequently, the need to earn an income pushing women into self-employment is stronger than the lack of factors pulling women into entrepreneurship (Yousafzai, Saeed \& Muffatto, 2015). Additionally, the traditional role of women is taking care of the family. The flexibility of self-employment allows them to combine housework with earning an income. This also pushes women to become entrepreneurs (Baughn \& Neupert, 2006). However, these elements suggest that the role of women as entrepreneurs will be mostly limited to subsistence businesses.

Once women own a business they are disadvantaged by ineffective formal institutions in various ways. For example, corrupt government officials are more difficult to deal with for 
women than for men (Amine \& Staub, 2009). Nevertheless, Estrin \& Mickiewicz (2011) find that male and female rates of entrepreneurship are equally sensitive to the strength of property rights and the incidence of corruption. Another formal institution which disadvantages women is inheritance laws. Women often cannot inherit assets and consequently cannot use them to satisfy collateral requirements (Amine \& Staub, 2009).

However, the largest burden on female entrepreneurs in emerging economies comes from gender-discriminatory informal institutions (Welter \& Smallbone, 2008) which have two main effects. First women still hold a very traditional role in society. Female entrepreneurs have to combine running their businesses with household responsibilities. This means that they have less time to spend on their businesses compared to male entrepreneurs and cannot fully exploit business opportunities (Pathak, Golz \& Buche, 2013). Because of time constraints it might also be difficult for female entrepreneurs to go through the time consuming process of formalizing their businesses so they potentially face more harassment from government officials (Amine \& Staub, 2009). The traditional role of women also leads to lower levels of human capital among female entrepreneurs (Baughn, Chua \& Neupert, 2006). Informal businesses and less educated entrepreneurs have less access to formal credit (Aga \& Reilly, 2011; Verheul et al, 2001).

A second aspect of gendered informal institutions is the negative view of society on female entrepreneurship. Subsequently, many female entrepreneurs lack the crucial networks and support of family and friends essential to access to business resources including capital (Amine $\&$ Staub, 2009). Furthermore the position of women in society increases the importance of family support during business startup because women (especially widows and young women) are not supposed to act independently (Welter \& Smallbone, 2008). This is also reflected by the restriction in freedom of movement often imposed on women (Estrin \& Mickiewicz, 2011). The lower value placed on female entrepreneurship also leads to female owned businesses being concentrated in high competition/low profit sectors (Baughn, Chua \& Neupert, 2006). Finally a negative societal view on female entrepreneurship leads to discrimination by capital providers (Youssafzai, Saeed \& Muffatto, 2015). 


\section{Tanzania}

Tanzania is the largest country in East Africa and one of the fastest growing economies in Africa with a real GDP growth of around 7\% in 2013 and 2014 compared to $5.3 \%$ in neighboring Kenya. Despite this, almost $36 \%$ of the population and $60 \%$ of women lived under the poverty line in 2012 (Mwasalwiba, Dahles \& Wakkee, 2012). The MSME (Micro, small and Medium sized enterprises) sector contributes between 27\% (MIT, 2012) and 40\% (Woldie et al, 2012) to the national GDP. Women owned businesses (WOEs) represent $54.3 \%$ of this sector. Hence, female entrepreneurs can potentially contribute a lot to Tanzania's economy demonstrating the importance of stimulating female entrepreneurship. Despite this, in 2012, only $25 \%$ of all firms were owned by women indicating that they mainly own small businesses (MIT, 2012).

After Tanzania's unification in 1964, it became a socialist nation with mainly large publicly owned and subsidized companies. Private initiatives and entrepreneurship were discouraged. The economic policy was reformed only in 1995, consequently, the entrepreneurial framework in Tanzania is still developing. In recent years, the country established good relations with many Asian countries leading to foreign investments and international trade. This is advantageous for Tanzania but many small businesses cannot compete with the cheaper and often higher quality products of Chinese firms (Mwasalwiba, Dahles \& Wakkee, 2012). This makes them less profitable and unattractive to lenders.

Since the 1990's, improvements in legislation led to a decrease in bureaucracy and corruption. However it still takes 40 days to obtain a construction permit and 20 days for a business license and corruption is frequent (Mwasalwiba, Dahles \& Wakkee, 2012; The World Bank \& The International Finance Corporation IFC, 2013). The financial sector in Tanzania is severely underdeveloped. Less than $20 \%$ of companies has a loan or credit line and more than $80 \%$ exclusively uses internal sources for investment. This might be caused by unachievable borrowing terms set by banks. Often an enormous amount of collateral is needed, more than 2.5 times the loan amount. (The World Bank \& IFC, 2013). As a result of the limited 
institutional environment, networks are of paramount importance in Tanzania. However, networking is harder for women who are sometimes prohibited to go out (Stevenson \& StOnge, 2005; Mwasalwiba, Dahles \& Wakkee, 2012). Tanzanian culture disadvantages female entrepreneurs in several other ways. Traditionally women stay at home and take care of the household (Mwasalwiba, Dahles \& Wakkee, 2012) leaving less time for business activities, therefore girls are less educated and do not receive business education. Furthermore women are discouraged from using property as collateral out of fear for failure (ILO,2014; Stevenson \& St-Onge, 2005).

To sum up our literature review, we conclude that the institutional framework composed of legal, normative and cognitive institutions has an important influence on business operations and strategies. In emerging economies, institutional voids lead to lower rates of entrepreneurship and business growth. One of the most important consequences of institutional voids is the problematic supply of business financing. Inefficient formal institutions lead to underdeveloped capital markets, discrimination by loan officers and unattractive borrowing terms. Female entrepreneurs are disproportionately disadvantaged by gendered formal and informal institutions. Previous research investigates the effects of institutions on entrepreneurship and access to finance on a national level. However, entrepreneurs are heterogeneous in their reactions to institutional forces. Entrepreneurial behavior is influenced by the context in which the entrepreneur operates and by business and entrepreneurial characteristics (Welter \& Smallbone, 2011). Consequently, it is important to look at the effect of institutions on the level of individual entrepreneurs.

We argue that an entrepreneur's reaction to institutional forces depends on his or her perception of these forces. How a female entrepreneur perceives normative institutions will determine what she considers acceptable behavior. It will also influence whether she believes she will face discrimination when applying for business finance. Similarly, a female entrepreneur's perception of cognitive institutions will affect her self-efficacy. It will also influence whether she believes she has enough knowledge to secure business financing. We will analyze the 
financing mix of Tanzanian female entrepreneurs and identify the main problems they face. We then study the underlying causes of these problems by linking them to entrepreneurs' perceptions of normative and cognitive institutions. We also identify the characteristics of female entrepreneurs and WOEs most sensitive to these problems which allows for specific policy recommendations.

\section{Data and methodology}

\section{Sample and data collection}

We gathered data on entrepreneurial characteristics, business characteristics and financing sources through surveys on 212 Tanzanian female entrepreneurs. Tanzania is divided in zones and regions. We selected the Central, Northern, Lake and Eastern zones because they contain many SMEs (MIT, 2012). Through random sampling we picked the Tanga, Dodoma, Dar es Salaam and Mwanza regions. Respondents were obtained by systematic sampling on lists solicited from local municipalities and training institutions. WOEs are businesses where women have the majority ownership; directly, manage and/or run the enterprise; make key business decisions and are responsible for risks associated with the business (Richardson, Howarth \& Finnegan, 2005).

The questionnaire used was developed by Stevenson \& St-Onge (2013) and modified and translated into Kiswahili to suit the Tanzanian environment. The new survey was piloted in 10 enterprises and feedback was incorporated in the main questionnaire which was executed in August 2013 using a face to face interview technique (Saunders, Lewis, \& Thornhill, 2003). The survey consists of mainly closed-end questions with multiple numerically coded answering options; some are nominal, some are ordinal. Only two questions in our survey require continuous responses: number of workers and age of the business. We also incorporated one open question which gauges ways in which respondents would solve perceived problems with respect to Tanzania's institutions. 
The variables defined in our study are separated into financing sources, business and entrepreneurial characteristics, problems respondents experience when accessing loans and respondents' perceptions of the institutional environment. The financing sources are: savings and sale of assets (only during the startup phase), loans from family and friends, bank loans, MFI loans, informal finance providers (money lenders and informal savings) and loans by external organizations like the government and donors. The use of these were measured using dummies separately during business start-up and during 2012 (referred to as the growth stage). The second group of variables consists of business characteristics. The main sector of activity of a WOE is measured by three dummies; Trade, Services and Manufacturing. Business size is measured by the amount of full time employees, business age is measured in years. Location is measured by an ordinal variable, businesses are located either in an urban or peri-urban (0) or rural (1) area. There are three levels of formalization: registration with the Municipality, the SME section of the MIT and with BRELLA. Business formality is measured using a dummy equal to 1 if a WOE is registered with at least one organization. Finally, organizational structure is measured by a dummy equal to 1 if the WOE is a sole proprietorship.

The third group of variables measures entrepreneurial characteristics. The entrepreneurs' age is measured using an ordinal variable equal to 1 if the respondent is less than 24 years old, equal to 2 if the respondent is between 25 and 39 years old, equal to 3 if the respondent is between 40 and 55 years old and equal to 4 for respondents older than 55. The respondent's education level is captured by an ordinal variable equal to 1 in case of primary school or less, 2 for secondary school, 3 for post-secondary but non-university education, 4 for vocational or technical training and 5 for university or college education. Female entrepreneurs' marital status is also measured with an ordinal variable. It equals 1 for single women, 2 for married women, 3 for divorced or separated women and 4 for widowed women. Finally, the network of an entrepreneur is measured by a dummy variable equal to 1 if the respondent has taken part in a business support program with other female entrepreneurs. 
The problems female entrepreneurs experience when accessing bank or MFI loans were selfreported and measured using survey questions that could be answered by "yes, this is a problem" (coded 0) or "no, this is not a problem" (coded 1). The difficulties measured were: high collateral requirements, high interest rates, a loan amount which is too small, a loan term which is too short, the need for a personal guarantee, the need for a co-signor and finally loan officers who do not take female entrepreneurs seriously. The perception of female entrepreneurs of their country's institutional framework was measured using statements with which respondents could agree, disagree, or have no opinion on. Topics ranged from regulation and harassment over business knowledge to support from family and gender equality.

The average age of entrepreneurs in our sample is 30.2 . Nearly $30 \%$ of our respondents have not completed secondary school. Nevertheless, they are eager to learn new skills as $50 \%$ participated in entrepreneurship- or small business management training. The majority of women $(65.57 \%)$ in our sample are married. $78 \%$ of respondents want to improve their business next year and half of them have already invested in a new product. This suggests that entrepreneurs want to invest in their business and might need external finance to grow.

The average business in our sample is only 9 years old. A large majority $(70 \%)$ of WOEs in our sample are urban. The average number of employees is 4.36 but the median is only 2 . Although almost all WOEs grow so that a worker is needed, only one in four companies succeeds in growing beyond the micro level (5 employees). $73 \%$ of WOEs are legally formalized, most of them at the lowest level. $83 \%$ of respondents are sole proprietorships. Most are active in the Services sector $(44.81 \%)$ and the Trade sector $(30.19 \%)$. Demand for finance is high, in combination with low access this will lead to problems. Table 1 summarizes the above mentioned descriptive statistics.

<Insert Table 1 here>

\section{Methodology}

The variables in our dataset are analyzed using univariate and multivariate statistics. More specifically we first use descriptive statistics and agglomerative, hierarchical clustering to 
determine the financing mix used by female entrepreneurs. We use the Jaccard distance measure to assess the similarity and dissimilarity of data points. Contrary to under the Simple Matching method, two observations are considered similar if they have a value of 1 for the same variables but not when both observations have a value of 0 (Gilbert, 1884; Everitt, 1986). In the two clusterings, (one for start-up and one for growth-stage financing) we opted for five clusters to achieve a balance between the Calinski-Harabasz stopping rule and what is most useful for interpretation (Calinski \& Harabasz, 1974). We checked the robustness of our results with a different distance measure (Simple Matching) and different clustering methods (Ward's method and Weighted Average Linkage) (Everitt, 1986).

Once we have insight in the financing mix, we deduce the main financing problems entrepreneurs encounter. We explore how these problems are influenced by entrepreneurs' perceptions of normative and cognitive institutions by providing relevant descriptives on the survey questions. Next, we use logistic regressions to identify which female entrepreneurs and WOEs suffer most from the three main problems that arise when accessing debt. Three logistic regressions are run, in each regression the problem (dependent variable) is regressed against entrepreneurial and business characteristics (independent variables). All three regression have the following functional form:

$$
\left(Y=1 \mid X_{k}\right)=P(Y)=\frac{e^{\alpha+\beta_{1} X_{1}+\beta_{2} X_{2}+\cdots+\beta_{k} X_{k}+\epsilon}}{1+e^{\alpha+\beta_{1} X_{1}+\beta_{2} X_{2}+\cdots+\beta_{k} X_{k}+\epsilon}}
$$

$\mathrm{Y}$ is equal to problems with collateral requirements (regression 1), problems with interest rates (regression 2) and problems with personal guarantees (regression 3), respectively; $\mathrm{P}(\mathrm{Y})$ denotes the probability of success $(\mathrm{Y}=1)$ given the explanatory variables. To allow for a more intuitive interpretation, in every regression success is defined as the female entrepreneur not experiencing a specific problem; $\mathrm{X}_{\mathrm{k}}$ is the set of independent variables (sector, business age, organizational structure, location, formality, entrepreneurial age, education, marital status, network, the interaction between organizational structure \& education, interaction between 
business formality \& education and interaction between business sector \& marital status); and $\alpha$ is the $\mathrm{Y}$ intercept.

For every regression we report the pseudo $\mathrm{R}^{2}$, the c-statistic, the Hosmer and Lemeshow Goodness of Fit value and the percentage of correctly classified observations to check the quality of the model (Lavalley, 2008; Sainani, 2014). We test the robustness of our results using probit regressions.

\section{Results}

Our results section is composed of three parts. In the first part the financing mix of WOEs is analyzed and the most important financing problems are identified. In the second section we discuss four underlying causes of these problems and how they are related to entrepreneurs' perceptions of cognitive and normative institutions. The third and final section deepens the analysis and identifies which female entrepreneurs and WOEs are most disadvantaged by these financing problems.

\section{Financing mix and financing problems}

Entrepreneurs' own savings are by far the most used method (85.38\%) when starting up a business followed by loans from family and friends (36.32\%). On average, these numbers show that it is difficult for starting WOEs to use external and formal financing methods. Nevertheless, demand for external finance during the growth stage is high, 55.19\% of WOEs applied for at least one external source in 2012. The financing instrument most used is bank loans (almost $25 \%$ of WOEs) but its use is still limited compared to the high percentages of own funds and loans from relatives used during the start-up phase. Moreover, almost $20 \%$ also use informal savings during the growth stage, marginally more frequently used than microfinance $(17.92 \%)$. The other financing instruments are much less popular. Table 2 gives an overview of the financing mix used during startup and growth.

<Insert Table 2 here> 
We use a cluster analysis to distinguish between different financing profiles among female entrepreneurs, this allows for a more detailed analysis of the financing mix. During startup, the largest cluster, $65 \%$ of respondents, uses a mix of financing sources, although personal funds (own savings and the sale of an asset) are predominant. Almost 30\% of respondents form another cluster using loans provided by family and friends supplemented by personal funds and informal instruments. A minority (less than 5\%) are gathered in a formal financing cluster using bank loans and microfinance to start up a business supplemented by $20 \%$ of cluster members with loans by relatives. Table 3 summarizes these results.

<Insert Table 3 here>

We check the robustness of our clusters with a different distance measure (Simple Matching) and a different clustering method (Ward's linkage \& Weighted Average Linkage). Results are comparable for Weighted Average Linkage, using Simple Matching or Ward's Linkage changes the results slightly.

We execute the same analysis for the year prior to the survey (labelled growth stage). The first cluster (50\% of WOEs) don't use any external finance, the majority of which does not apply for finance. The second cluster contains slightly more than a third of WOEs. They all use bank loans and/or microfinance to finance the growth of their business combined with loans provided by family and friends and informal finance. There is also a cluster encompassing only $6 \%$ of respondents who use only informal finance. We again check the robustness, the results are comparable when we use Ward's linkage and robust when we use weighted average linkage. Table 4 contains the results of the cluster analysis.

<Insert Table 4 here>

From these numbers we identify following financing problems. Firstly, startups have difficulties getting loans from banks or MFIs. Instead they use personal funds (own savings, sale of an asset \& loans from family and friends). This is in line with previous research showing that institutional voids create the need to bootstrap to access resources. Secondly access to formal loans is easier for growing WOEs but it is not sufficient, instead they are being 
complemented with informal funds and personal savings. This is in line with previous research describing the importance of networks (i.e. savings groups) to access resources. More than $70 \%$ of respondents name access to finance as the most important constraint to starting and growing a business. Especially loans from banks and MFIs seems to be problematic. This illustrates what has been shown by previous research; namely that institutional voids in emerging economies make it harder for businesses to get loans.

\section{Underlying mechanisms}

We now turn to the mechanisms underlying these problems and how they are influenced by entrepreneurs' perceptions of normative and cognitive institutions. Our data shows that success rates during the growth stage, for bank (85\%) and for microfinance (93\%) loan applications are very high. Instead, application rates are low; $28 \%$ for MFI loans and $18 \%$ for bank loans. In Table 5 we report the main barriers of access to formal loans as mentioned by female entrepreneurs. The three most pressing issues entrepreneurs experience when borrowing from banks or MFIs are all related to borrowing terms. $85 \%$ of respondents experience difficulties with high interest rates, $83 \%$ with collateral requirements and $71 \%$ of respondents mention the need for a personal guarantee. These unattractive borrowing terms help to explain the low application rates for bank and microfinance loans.

<Insert Table 5 here>

Table 6 reports female entrepreneurs' perceptions of normative and cognitive institutions. Being an entrepreneur is an acceptable profession for women and only $12 \%$ of respondents mention lack of family support as a barrier when starting up a business. Nevertheless, when their business starts to grow, $30 \%$ of female entrepreneurs complain about a lack of family support. This is perhaps related to the fact that as the business grows, women spend less time on their traditional role, namely taking care of household responsibilities. Female entrepreneurs are also rather positive about their chances of accessing finance. $74.16 \%$ of respondents feel that women and men have the same opportunities to access finance. Furthermore, $82.25 \%$ feel that they have the same opportunities to own \& register property. Nonetheless, only $38 \%$ of 
women feel that access to credit is women friendly and $42 \%$ of respondents believe that loan officers don't take women seriously.

With respect to cognitive institutions, respondents feel that information and advice on how to start a business is readily available. Moreover $81.34 \%$ of respondents feel that women and men have equal access to entrepreneurship training. Furthermore, a majority of respondents state that their education adequately prepared them for their role as entrepreneur. However this is contradicted by the fact that $91 \%$ of respondents believe they need more skills to be successful entrepreneurs. $60.19 \%$ of female entrepreneurs mention a lack of knowledge on new markets, $73.68 \%$ bring up a lack of IT skills, $66.03 \%$ mention a lack of knowledge on business development services and $72.25 \%$ state they are insufficiently informed about business regulations. Most importantly however, slightly more than half of female entrepreneurs state that information about financing sources is not widely available.

$<$ Insert Table 6 here $>$

Based on these data, following main conclusions can be drawn. First, the low application rates coupled with high success rates suggest that entrepreneurs only apply for loans if they think they will succeed. Consequently the low use of formal loans is related to a lack of applications, not a lack of credit supply. Second, female entrepreneurs perceive borrowing terms to be extremely unattractive, which prevents them from applying for bank and microfinance loans. Third, although entrepreneurs' perceptions of normative institutions are generally positive, respondents perceive some gender inequality when it comes to access to finance. Previous research shows that a negative societal image on female entrepreneurship discourages otherwise competent individuals from starting a business (Pathak, Golz \& Buche, 2013). Along these lines, we conjecture that perceived gender-differences in access to finance is discouraging female entrepreneurs in our dataset from applying for bank and microfinance loans. Fourth, although entrepreneurs' perceptions of cognitive institutions are generally positive, female entrepreneurs feel that they have insufficient access to information about financing sources. 
Again, this perceived difference in access to financial information seems to prevent female entrepreneurs from applying for formal loans.

\section{The most disadvantaged female entrepreneurs and WOEs}

We now deepen the analysis and investigate which female entrepreneurs face the most problems with collateral, interest rates and personal guarantee requirements when borrowing from a financial institution (bank or MFI). This allows policy makers or banks and MFIs to focus their efforts on the most financially excluded entrepreneurs. Borrowing terms are used by creditors to reduce risk and asymmetric information. Credit risk is related to characteristics of the debtor (Menkhoff, Neuberger \& Suwanaporn, 2006; Hanedar, Broccardo \& Bazzana, 2014). We first build a baseline model where we regress difficulties with collateral, interest rates and personal guarantees (dependent variables) against business and entrepreneurial characteristics (independent variables). We include the following characteristics: business sector, business age, organizational structure, location, formality, age of the entrepreneur, education, marital status and network.

We also include an extended model with interaction effects because we expect the effects of business formalization and organizational structure to vary with the education level of an entrepreneur. Educated entrepreneurs are better at exploiting business opportunities, their firms are generally more successful. Firms led by more educated female entrepreneurs are therefore less risky (Barringer, Jones \& Neubaum, 2005, Verheul et al, 2001) and are subject to less strict lending requirements (Abdulsaleh \& Worthington, 2013). As such we expect, sole proprietorships led by highly educated entrepreneurs to experience less problems compared to sole proprietorships led by less educated entrepreneurs. Similarly, we expect informal WOEs led by more educated entrepreneurs to experience less problems compared to informal WOEs led by less educated entrepreneurs. In order to investigate these moderating effects we include the following interaction terms: organizational structure*education and formalization*education. We observe that the quality of our model increases when we add the interaction terms. 
Table 7 presents the results of our regression analyses. Panel A displays results for issues with collateral requirements, panel $\mathrm{B}$ for issues with interest rates and panel $\mathrm{C}$ for issues with personal guarantee requirements. In every panel, columns 1 and 2 correspond to the baseline model and columns 3 and 4 to the extended model. In all regressions, an independent variable equal to 1 implies that a female entrepreneur does not experience any problems with that borrowing term.

$<$ Insert Table 7 here $>$

As can be seen in table 7, both business- and entrepreneurial characteristics influence the likelihood that female entrepreneurs report issues with collateral, interest rates or personal guarantees. However the effects of business characteristics are slightly more robust than the effects of entrepreneurial characteristics. We see that WOEs in the trade sector are the most disadvantaged as they are more likely to experience issues will all three borrowing terms. Businesses in the manufacturing sector are more likely to suffer from personal guarantee requirements.

Surprisingly formalized businesses are also much more likely to experience difficulties with high interest rates, personal guarantee requirements and collateral requirements. Furthermore, the extended model demonstrates that education positively moderates the impact of formalization on problems with interest rates and personal guarantee requirements. When calculating the margins, we find that the probability of an informal business experiencing problems with interest rates when the owner has at most completed primary school is $45 \%$ compared to $40 \%$ when the owner has attended university or college. For a formal business these probabilities are respectively equal to $92 \%$ and $87 \%$. The probability of an informal business suffering from collateral requirements when the owner has at most completed primary school is $46 \%$ compared to $31 \%$ when the owner has a university or college degree. For a formal business these probabilities are respectively $88 \%$ and $78 \%$. In panel $\mathrm{B}$ we see that married entrepreneurs are less likely to suffer from personal guarantee requirements and high 
interest rates (only the extended model). The same applies to female entrepreneurs who are divorced or separated.

Remarkably, in panel A we observe that female entrepreneurs who are part of a network have a higher chance of reporting problems with collateral requirements. Furthermore, the extended model indicates that WOEs organized as sole proprietorships are also more inclined to suffer from collateral requirements (panel A, column 3). This relationship is once again positively moderated by education. The probability of a partnership, limited liability or cooperative experiencing problems if the entrepreneur has at most attended primary school is equal to 59\%, compared to $51 \%$ if the owner has a university or college degree. The same comparison for a solely owned WOE yields probabilities of respectively $92 \%$ and $84 \%$. The baseline model indicates that there is also a direct effect of education on issues with collateral requirements but this relationship is not robust. It disappears once the interaction terms are incorporated.

The negative relationship between networks and collateral issues is remarkable given previous research. Networks are used in contexts with inefficient institutions, like Tanzania, in order to reduce risk and information asymmetry and improve access to resources (Peng \& Heath, 1996). Yet for Tanzanian female entrepreneurs being part of a network aggravates problems associated with bank or MFI loans. This could be related to our measure of networks which captures relationships between the respondent and other female entrepreneurs, not between the respondent and loan officers. It is likely that these relationships are more important to access informal finance or information and less important to access formal finance. Nevertheless this does not explain why being part of a network negatively influences access to finance.

The negative effect of formalization also seems strange at first because past research establishes that business formalization reduces risk and eases access to finance (MIT, 2012). This could signify that although informal businesses are required to provide more collateral they are more willing or capable to do so resulting in fewer problems. Finally, prior research shows that sole proprietorships are more risky because there is no separation between the business and the entrepreneur (Kira \& He, 2012). Additionally single owners have no partners to supplement 
their knowledge or experience (Carter, William \& Reynolds, 1997). This explains the negative influence of sole proprietorships on issues with collateral requirements we find.

The quality of our regressions is good. The adjusted $\mathrm{R}^{2}$ 's are between 0.07 and 0.15 . Furthermore our models have good discriminatory capability. All regressions have c-statistics north of $69 \%$ and on average more than $80 \%$ of observations are correctly classified. The sensitivity of our collateral regressions are very low but this is probably caused by the high proportion of respondents that experience problems. Because classification is not the goal of our analysis, this is not problematic and more importance should be given to the goodness of fit of our models (Hosmer \& Lemeshow, 2000). All regressions exhibit adequate goodness of fit as demonstrated by the insignificant Hosmer and Lemeshow goodness of fit tests. To test the robustness of our results we replicate every regression (both baseline and extended models) using probit (see columns $2 \& 4$ in every panel). Our results are fairly robust.

\section{Conclusions and discussion}

\section{Summary of main results}

We investigate the financing mix of Tanzanian WOEs, identify the most important problems that female entrepreneurs encounter in accessing finance, and link them to entrepreneurs' perceptions of the institutional environment.

We find that female entrepreneurs mainly rely on personal savings, loans from family and friends and other informal sources to finance their businesses. The use of bank loans and microfinance loans is very limited, especially during business startup. We find that this is related to a lack of applications and identify three mechanisms contributing to this. First, loan terms are unattractive. $85.38 \%$ of respondents complain about high interest rates, $83.96 \%$ complain about high collateral requirements and $70.75 \%$ criticize the need for a personal guarantee. Second, respondents feel discouraged from applying because they believe they will be rejected. $62 \%$ of respondents feel that access to credit is not women friendly and $42 \%$ believe that loan officers do not take them seriously. These perceived barriers fuel fear of 
getting rejected which prevents female entrepreneurs from applying. Third, a lack of financing knowledge might also restrict the use of bank and microfinance loans. $91 \%$ of respondents believe they need more skills in order to be successful entrepreneurs and more than half of female entrepreneurs mention that they have insufficient knowledge about financing opportunities. Given that female entrepreneurs only apply for loans if they believe they will be accepted, a lower level of self-efficacy (confidence in your abilities to succeed) might prevent them from applying. A lower level of human capital also makes female entrepreneurs more risky to credit providers, further exacerbating the problem of unattractive borrowing terms.

We deepen our analysis by investigating which female entrepreneurs and WOEs report most issues with borrowing terms. We find that WOEs in the trade sector as well as formalized WOEs are most likely to complain about collateral requirements, interest rates and personal guarantee requirements. Furthermore, unmarried owners as well as female entrepreneurs who are part of a network together with other female entrepreneurs suffer more from high collateral requirements. A higher education alleviates problems for formal businesses and sole proprietorships. Finally contrary to previous research, our data shows that entrepreneurs who are part of a network are more likely to experience problems with collateral requirements. Also contrary to previous research, we find that formalized businesses are more likely to experience issues with collateral requirements, interest rates and personal guarantee requirements.

\section{Contributions and policy recommendations}

While exploratory, we believe this study makes some important contributions to theory. Previous research studying entrepreneurship from an institutional viewpoint explains variations in national levels of (female) entrepreneurship through variations in the institutional climate. While these studies show an impact of institutions on business finance, they mostly create insights on a national level, not on the level of individual entrepreneurs. However entrepreneurs are heterogeneous in their reactions to their institutional and business environment. We take a next step by exploring how individual entrepreneurs' perceptions of gendered normative and cognitive institutions prevent them from applying for formal loans. 
Our results contrast with previous findings in two main ways. First we show that entrepreneurs' perceptions of institutions are different from the way the institutional environment in emerging economies is typically described. More specifically, previous research describes a negative societal view on female entrepreneurship leading to discrimination by loan officers as well as difficulties for women to use assets as collateral. However our data shows that our respondents perceive "entrepreneur" to be an acceptable role for women and that both genders have equal opportunities to register and use assets as collateral. Nevertheless, respondents do feel that access to finance is hard for female entrepreneurs and consequently might still be discouraged from applying for a loan. Second, our findings also contrast with previous research because they suggest that perceptions of institutions primarily drive financing behavior and not the institutions themselves. Previous research stresses the effect of institutional voids on the supply of business finance where it leads to discrimination and a lack of credit providers. Our data shows that the influence of entrepreneurs' perceptions on their demand for formal loans may actually be more important. Female entrepreneurs perceive that they have less chances of getting a loan and consequently fail to apply for one. This is independent of whether this perception matches reality or not.

We make the following policy recommendations. Female entrepreneurs feel that access to finance is not gender neutral and some entrepreneurs state that they are not taken seriously by loan officers. Ensuring loan officers remain unbiased and take objective decisions might alleviate this situation. Nevertheless, the importance of the influence of perceptions implies that policy makers will not be able to promote the use of formal loans simply by enforcing gender equality or anti-discrimination laws. Instead they need to focus on changing entrepreneurs' perceptions and educating them. The need for IT education as well as providing women with information on markets, business regulations and business development support services is especially large. 


\section{Limitations and suggestions for future research}

Our research is not without flaws. Our measure of the entrepreneur's network is imperfect and consequently does not capture the entire impact of business networks on issues with collateral requirements, interest rates or personal guarantee requirements. Moreover it is possible that loan characteristics influence the borrowing terms entrepreneurs are subject to and consequently the problems they experience fulfilling them. Hence once could try controlling for loan size or loan term when looking at problems with borrowing terms. We suggest the following topics for future research. First, our investigation into the influence of perceptions of institutions on individual behavior is exploratory in nature. Future research could try to investigate the causality between both concepts. Second, currently, informal savings groups as well as digital lending schemes like Tigo Nivushe (Gordon, 2016) are being used to alleviate problems related to bank and microfinance loans. Although very useful they usually offer small loans, insufficient for growing businesses. Future research could look into alternatives for formal loans, better suited to the needs of female entrepreneurs. Finally business formality and networking with other female entrepreneurs are associated with more collateral and personal guarantee issues. Future research could be aimed at identifying underlying mechanisms.

\section{References}

Abdulsaleh, A., \& Worthington, A. (2013). Small and Medium-Sized Enterprises Financing: A Review of Literature. International Journal of Business and Management , 8, 36.

Acs, Z., and E. Autio. 2010. The global entrepreneurship and development index: A brief explanation. Paper presented at the How to make the UK more entrepreneurial event, March, in London.

Aga, G. A., \& Reilly, B. (2011). Access to credit and informality among micro and small enterprises in Ethiopia. International Review of Applied Economics, 25(3), 313-329. http://doi.org/10.1080/02692171.2010.498417

Amine LS, Staub KM. 2009. Women entrepreneurs in sub-Saharan Africa: An institutional theory analysis from a social marketing point of view. Entrepreneurship \& Regional Development 21(2):183-211.

Barbosa, E., \& Moraes, C. d. (2004). Determinants of the Firm's Capital Structure: The Case of the Very Small Enterprises. From http://EconPapers.repec.org/RePEc:wpa:wuwpfi:0302001

Barringer, B., Jones, F., \& Neubaum, D. (2005). A quantitative content analysis of the characteristics of rapidgrowth businesses and their founders. Journal of Business Venturing , 20 (2005), 663-687.

Baughn CC, Chua B-L, Neupert KE. 2006. The Normative Context for Women's Participation in Entrepreneurship: A Multicountry Study. Entrepreneurship Theory and Practice 30(5):687-708. 
Beck, T., Levine, R. \& Loayza, N. (2000). Finance and the sources of growth. Journal of Financial Economics, 58 (2000), 261 - 300

Bhat, S \& Khan, R. (2014). Entrepreneurship and Institutional Environment: Perspectives from the Review of Literature. European Journal of Business and Management, 6(1), 84-97

Biggart, N.W. \& Guillen, M. F. (1999). Developing Difference: Social Organization and the Rise of the Auto Industries of South

Bohata, M., and J. Mladek. 1999. The development of the Czech SME sector. Journal of Business Venturing 14: 461-73.

Bruton, D. \& Ahlstrom, G. D. (2006). Venture Capital in Emerging Economies: Networks and Institutional Change. Entrepreneurship Theory and Practice, March (2006), 299-320

Bruton, G. D. \& Ahlstrom, D. (2003). An institutional view of China's venture capital industry Explaining the differences between China and the West, Journal of Business Venturing, 18 (2003), 233-259

Bruton, G. D., Ahlstrom, D. \& Li, H-L, (2010). Institutional Theory and Entrepreneurship: Where Are We Now and Where Do We Need to Move in the Future?. ET\&P, May 2010, 421-440

Caliński, T. \& Harabasz, J. 1974. A dendrite method for cluster analysis. Communications in Statistics 3: 1-27.

Chen, H. (2013). A Review of Institutional Theory and Entrepreneurship. [Book Chapter], Retrieved from https://books.google.be/books?id=7fNHAAAAQBAJ\&pg=PA719\&lpg=PA719\&dq=Chen+2013+A+review +of+Institutional+Theory+and+Entrepreneurship\&source=bl\&ots=fdMOaT412M\&sig=tCjFLfvgqIPRNY7ddrLWF7zoc\&hl=fr\&sa=X\&ved=0ahUKEwjJ47aK3oTOAhVrCMAKHRYHCasQ6AEIITAA\#v=onepage\&q $=$ Chen $\% 202013 \% 20 \mathrm{~A} \% 20$ review\%20of\%20Institutional\%20Theory\%20and $\% 20$ Entrepreneurship $\& \mathrm{f}=$ false

Demirgüç-Kunt, A. \& Maksimovic, V. (1999). Institutions, financial markets, and firm debt maturity. Journal of Financial Economics, 54 (1999), 295-336

DiMaggio, P. (1988). Interest and agency in institutional theory in Institutional patters and culture, Cambridge. Ballinger Publishing Company, Cambridge, pp 3-22

Estrin S, Mickiewicz T. 2011. Institutions and female entrepreneurship. Small Business Economics 37(4):397415.

Everitt, B. 1986. Cluster Analysis. 2nd ed. Chichester, UK: Wiley

Gilbert, G. K. 1884. Finley's tornado predictions. American Meteorological Journal 1: 166-172

Gordon, C. (2016, March 2). Tigo Nivushe, Tanzania: 5 Ways to Build Trust in Digital Lending. Retrieved from http://www.cgap.org/blog/tigo-nivushe-tanzania-5-ways-build-trust-digital-lending

Green, C., Kimuyu, P., Manos, R., \& Murinde, V. (2007). How do Small Firms in Developing Countries Raise Capital? Evidence from a Large-Scale Survey of Kenyan Micro and Small-Scale Enterprises. In M. Hirschey, K. John, \& A. K. Makhija, Issues in Corporate Governance and Finance (Advances in Financial Economics, Volume 12) (pp. 379 - 404). Emerald Group Publishing Limited.

Hainz, C. (2003). Bank competition and credit markets in transition economies. Journal of Comparative Economics, 31, 223-245. http://doi.org/10.1016/S0147-5967(03)00021-0

Hanedar, E. Y., Broccardo, E., \& Bazzana, F. (2014). Collateral requirements of SMEs: The evidence from lessdeveloped countries. Journal of Banking and Finance , 38, 106-121.

Hitt, M. A., Ahlstrom, D., Dacin, M. T., Levitas, E. \& Svobodina, L. (2004). The Institutional Effects on Strategic Alliance Partner Selection in Transition Economies: China vs. Russia. Organization Science, 2 (15), 173-185

Hoffman, A. J. 1999 'Institutional evolution and change: Environmentalism and the US chemical industry'. Academy of Management Journal, 42: 351-371.

Hoskisson, R., Eden, L., Lau C-M. and Wright, M., 2000, Strategies in emerging markets. Academy of Management Journal, 43(3), 249- 267

Hosmer, D., \& Lemeshow, S. (2000). Applied Logistic Regression (2nd Ed.). Hoboken: Wiley-Interscience.

ILO (2014). Women's Entrepreneurship Development in Tanzania: Insights and Recommendations 
Johnson, B., \& Christensen, L. (2004). Educational research: Quantitative, qualitative and mixed approaches (2nd ed.). Boston: Pearson

Khanna, T. \& Palepu, K. (1997). Why focused strategies may be wrong for emerging markets. Harvard Business Review, 75(4), 41-51.

Khanna, T. and Palepu, K., 2010, Winning in Emerging Markets: A Roadmap for Strategy and Execution. Harvard Business Press

Kira, A. R., \& He, Z. (2012). The impact of firm characteristics in access of financing by small and mediumsized enterprises in Tanzania (Survey). International Journal of Business and Management , 7 (24), 108-112.

Korea, Taiwan, Spain, and Argentina, American Sociological Review, 64 (5), 722-747"

Kwok, C. C. Y. \& Tadesse, S. (2006). National Culture and Financial Systems. Journal of International Business Studies, 2 (37), 227-247

La Porta, R., F. Lopez-de-Silanes, A. Shleifer, and R. Vishny. 1997. Legal determinants of external finance. Journal of Finance 52: 1131-50.

La Porta, R., F. Lopez-de-Silanes, A. Shleifer, and R. Vishny. 2000. Investor Protection and corporate governance. Journal of Financial Economics, 58 (2000), 3-27

LaValley, M. P. (2008). Logistic Regression. Statistical Primer for Cardiovascular Research. Retrieved from http://circ.ahajournals.org/

Menkhoff, L., Neuberger, D., \& Suwanaporn, C. (2006). Collateral-based lending in emerging markets: Evidence from Thailand. Journal of Banking \& Finance , 30, 1-21

Meyer, K. E. (2001). Institutions, Transactions Costs, and Entry Mode Choice in Eastern Europe. Journal of International Business Studies, 2 (32), 357-367

MIT. 2012. National Baseline Survey Report for Micro, Small, and Medium Enterprises in Tanzania. Dar es Salaam, Tanzania: United Republic of Tanzania.

Molina-Azorin, J. F. (2012). Mixed Methods Research in Strategic Management: Impact and Applications, Organizational Research Methods. 15 (1), 33-56

Mwasalwiba, E., Dahles, H. \& Wakkee, I., (2012). Graduate Entrepreneurship in Tanzania: Contextual Enablers and Hindrances. European Journal of Scientific Research, 76(3), 386-402

North, D. C. 1990. Institutions, institutional change and economic performance. Cambridge: Cambridge University Press.

Pathak S, Golz S, Buche MW. 2013. Influences of gendered institutions on women's entry into entrepreneurship. International Journal of Entrepreneurial Behaviour \& Research 19(5):478-502.

Peng, M. W. \& Heath, P. S. (1996). The Growth of the Firm in Planned Economies in Transition: Institutions, Organizations, and Strategic Choice. The Academy of Management Review, 2 (21), 492-528

Peng, M.W. (2001). How entrepreneurs create wealth in transition economies. Academy of Management Executive, 15(1), 95-110.

Peng,M.W. (2002). "Cultures, Institutions, and Strategic Choices:Towards an Institutional Perspective on Business Strategy." In M. Gannon and K. Newman (eds.), The Blackwell Handbook of Cross-Cultural Management. (pp. 52-66). Cambridge, UK: Blackwell

Powell,W. (1996). "Commentary on the Nature of Institutional Embeddedness." Advances in Strategic Management 13, 293-300.

Qi, Y., Roth, L. \& Wald, J. K. (2010). Political rights and the cost of debt. Journal of Financial Economics, 95 (2010), 202-226

Richardson, P., Howarth, R., \& Finnegan, G. (2005). The Challenges of Growing Small Businesses: Insights from Women Entrepreneurs in Africa. Series on Women's Entrepreneurship Development and Gender Equality - WEDGE, SEED Working Paper No. 47 . Geneva: International Labour Organization.

Sainani, K. L. (2014). Logistic Regression. PM\&R Vol. 6, Iss. 12, 2014, p1175 - 1162.

Saunders, M., Lewis, P., \& Thornhill, A. 2003. Research Methods for Business Students (3rd ed.). Sydney: Prentice Hall. 
Scalera, D. \& Zazzaro, A. (2009). Do Inter-Firm Networks Make Access to Finance Easier? Issues and Empirical Evidence, [Working Paper] MoFIR working paper n.25, July 2009

Scheela, W. \& Jirrapanun, T. (2012). Do institutions matter for business angel investing in emerging Asian markets?, Venture Capital, 14 (4), 289-308

Scheela, W., Isidro, E., Jittrapanun, T. \& Trang, N. T. T. (2015). Formal and informal venture capital investing in emerging economies in Southeast Asia, Asia Pacific Journal of Management, 32 (2015), 597 - 617

Scott, R. 1995 Institutions and organizations. Thousand Oaks, CA: Sage.

Scott, W. R. 2001. Institutions and Organizations. Sage Publications, Thousand Oaks, CA.

Smallbone, D., \&Welter, F. (2001). The distinctiveness of entrepreneurship in transition economies. Small Business Economics, 16(4), 249-262.

Stephan, A., Talavera, O. \& Tsapin, A. (2011). Corporate debt maturity choice in emerging financial markets. The Quarterly Review of Economics and Finance, 51 (2011), 141-151

Stevenson, L., \& St-Onge, A. (2013). National Assessment of Women's Entrepreneurship Development (WED) Framework Conditions: Assessors Guide. In ILO-WED, Women's Entrepreneurship Development Programme (p. 155). ILO.

Stevenson, L., \& St-Onge, A. 2005. Support for Growth-oriented Women Entrepreneurs in Tanzania. In ILO (Ed.), Programme on Boosting Employment through Small Enterprise Development Job Creation and Enterprise Department. International Labor Organization: ILO. The impact of firm characteristics in access of financing by small and medium-sized enterprises in Tanzania.(Survey)

The World Bank \& The International Finance Corporation, (2013)., Tanzania Country Profile 2013, Enterprise Surveys

Verheul, I., Wennekers, S., Audretsch, D., \& Thurik, R. (2001). An eclectic theory of entrepreneurship: policies, institutions and culture. Tinbergen Institute Discussion paper no. TI 2001-030/03 .

Welter F, Smallbone D. 2008. Women's Entrepreneurship from an Institutional Perspective: the Case of Uzbekistan. International Entrepreneurship and Management Journal(4):505-520.

Welter F, Smallbone D. 2011. Institutional Perspectives on Entrepreneurial Behavior in Challenging Environments. Journal of Small Business Management 49(1):107-125.

Woldie, B., Mwita, I., \& Saidimu, J. (2012). Challenges of microfinance accessibility by SMEs in Tanzania. Thunderbird International Business Review, 54, 567-579.

Wurgler, J., 2000. Financial markets and the allocation of capital. Journal of Financial Economics 58, $187-214$.

Yousafzai SY, Saeed S, Muffatto M. 2015. Institutional Theory and Contextual Embeddedness of Women's Entrepreneurial Leadership: Evidence from 92 Countries. Journal of Small Business Management 53(3):587604.

Zahra, S. A., Ireland, D. A., Gutierrez, I. \& Hitt, M. A. (2000). Privatization and Entrepreneurial Transformation: Emerging Issues and a Future Research Agenda. The Academy of Management Review, 3 (25),509-524

Zervos, N., \& Makani, V. L. (2014, November 3). 2014 Project Finance Report: Tanzania. (Euromoney Institutional Investor PLC) Retrieved April 27, 2016 from International Financial Law Review: http://www.iflr.com/Article/3396792/2014-Project-finance-report-Tanzania.html

Zheng, X., Ghoul, S. E., Guedhami, O. \& Kwok, C. C. Y. (2012). National Culture and Corporate Debt Maturity. Journal of Banking \& Finance, 36 (2012), 468-488 


\section{List of tables}

Table 1: Descriptive statistics

\begin{tabular}{|c|c|c|c|c|c|}
\hline \multicolumn{6}{|l|}{ Panel A: Ordinal and continuous variables } \\
\hline Variable & Mean & Median & Stddev & Min & $\operatorname{Max}$ \\
\hline Business size & 4.36 & 2 & 6.41 & 0 & 60 \\
\hline Business age & 9.12 & 7 & 6.84 & 1 & 33 \\
\hline Age of the entrepreneur & 1.92 & 2 & 0.62 & 1 & 4 \\
\hline Education of the entrepreneur & 2.62 & 2 & 1.52 & 1 & 5 \\
\hline Marital status of the entrepreneur & 1.90 & 2 & 0.69 & 1 & 4 \\
\hline \multicolumn{6}{|l|}{ Panel B: Dummy variables } \\
\hline Variable & \multicolumn{2}{|c|}{$\%$ of WOEs in "0" category } & \multicolumn{3}{|c|}{$\%$ of WOEs in " 1 " category } \\
\hline Trade sector $(0=$ not active in this sector $)$ & \multicolumn{2}{|l|}{69.81} & \multicolumn{3}{|l|}{30.19} \\
\hline Services sector $(0=$ not active in this sector $)$ & \multicolumn{2}{|l|}{55.19} & \multicolumn{3}{|l|}{44.81} \\
\hline $\begin{array}{l}\text { Manufacturing sector }(0=\text { not active in this } \\
\text { sector })\end{array}$ & \multicolumn{2}{|l|}{75} & \multicolumn{3}{|l|}{25} \\
\hline Location $(0=$ Urban or peri-urban $)$ & \multicolumn{2}{|l|}{95.75} & \multicolumn{3}{|l|}{4.25} \\
\hline Formalization $(0=$ not formalized $)$ & \multicolumn{2}{|l|}{27.83} & \multicolumn{3}{|l|}{72.17} \\
\hline $\begin{array}{l}\text { Organizational structure }(0=\text { not organized as a } \\
\text { sole proprietorship) }\end{array}$ & \multicolumn{2}{|l|}{17.45} & \multicolumn{3}{|l|}{82.55} \\
\hline $\begin{array}{l}\text { Network }(0=\text { Not participated in support program } \\
\text { with other female entrepreneurs })\end{array}$ & \multicolumn{2}{|l|}{70.14} & \multicolumn{3}{|l|}{29.86} \\
\hline
\end{tabular}

Table 2: Financing mix during startup and growth stages (in \% of WOEs)

\begin{tabular}{|l|l|l|}
\hline Financing sources & Startup & Growth \\
\hline Own savings & $85.38 \%$ & $-*$ \\
\hline Family \& Friends & $36.32 \%$ & $13.68 \%$ \\
\hline Bank loans & $16.51 \%$ & $23.58 \%$ \\
\hline Informal savings & $15.57 \%$ & $18.40 \%$ \\
\hline Microfinance & $14.15 \%$ & $17.92 \%$ \\
\hline Sell an asset & $4.72 \%$ & $-*$ \\
\hline Moneylender & $3.77 \%$ & $3.77 \%$ \\
\hline Government loan & $1.42 \%$ & $2.36 \%$ \\
\hline Donor & $0.94 \%$ & $1.89 \%$ \\
\hline
\end{tabular}

* The financing sources "own savings" and "sell an asset" were not an option in the survey questions related to growth stage financing

Table 3: Cluster analysis at startup

\begin{tabular}{|l|l|l|l|l|l|}
\hline Financing sources & Cluster 1 & Cluster 2 & Cluster 3 & Cluster 4 & Cluster 5 \\
\hline Personal funds & 0.99 & 0.79 & 0 & 0 & 0 \\
\hline Formal finance & 0.33 & 0 & 1 & 0 & 0 \\
\hline Family \& Friends loans & 0.09 & 1 & 0.2 & 0 & 0 \\
\hline Informal finance & 0.21 & 0.10 & 0 & 1 & 0 \\
\hline External organizations finance & 0.03 & 0 & 0 & 0 & 1 \\
\hline Cluster size (in \% of WOEs) & 65.09 & 29.25 & 4.72 & 0.47 & 0.47 \\
\hline
\end{tabular}

Note: These figures represent each cluster's mean value for each financing source 
Table 4: Cluster analysis during growth stage

\begin{tabular}{|l|l|l|l|l|l|}
\hline Financing sources & Cluster 1 & Cluster 2 & Cluster 3 & Cluster 4 & Cluster 5 \\
\hline Formal finance & 0 & 1 & 0 & 0 & 0.5 \\
\hline Family \& Friends loans & 0 & 0.24 & 0 & 1 & 0.13 \\
\hline Informal finance & 0 & 0.33 & 1 & 0 & 0.63 \\
\hline External organizations finance & 0 & 0 & 0 & 0.1 & 1 \\
\hline Cluster size (in \% of WOEs) & 50 & 35.38 & 6.13 & 4.72 & 3.77 \\
\hline
\end{tabular}

Note: These figures represent each cluster's mean value for each financing source.

Table 5: Problems when accessing bank or MFI loans

\begin{tabular}{|l|l|}
\hline Problem & Percentage of WOEs \\
\hline Interest rates are too high & 85.38 \\
\hline Collateral requirements are too high & 83.96 \\
\hline Required to provide a personal guarantee & 70.75 \\
\hline The term of the loan is too short & 67.92 \\
\hline The amount of approved loan is too small & 66.04 \\
\hline Required to have a co-signor & 59.91 \\
\hline Women entrepreneurs are not taken seriously by loan officers & 41.98 \\
\hline
\end{tabular}

Table 6: Female entrepreneurs' perceptions of the institutional environment

\begin{tabular}{|l|l|}
\hline Statement & \% of female entrepreneurs who agree \\
\hline Getting support from my family is a barrier to starting up my business & 11.79 \\
\hline Getting support from my family is a barrier to growing my business & 29.86 \\
\hline Loan officers don't take female entrepreneurs seriously & 41.98 \\
\hline Access to credit is women friendly & 38.28 \\
\hline Women and men have the same opportunities to access business finance & 74.16 \\
\hline Women and men have the same opportunities to own and register property & 83.25 \\
\hline $\begin{array}{l}\text { Women and men have the same opportunities to participate in entrepreneurship } \\
\text { education and training programmes }\end{array}$ & 81.34 \\
\hline Entrepreneur is seen as an acceptable role for women by society & 80.38 \\
\hline Finding information on how to start a business is a challenge & 20.28 \\
\hline My previous education \& experience prepared me well for my role as entrepreneur & 58.37 \\
\hline Insufficient knowledge on new markets is a barrier to growing my business & 60.19 \\
\hline I need more skills to operate my business successfully and make it grow & 91.39 \\
\hline Making better use of IT would enable female entrepreneurs to compete more effectively & 73.68 \\
\hline $\begin{array}{l}\text { Information about business development services is widely available to female } \\
\text { entrepreneurs }\end{array}$ & 33.97 \\
\hline Information about financing sources is widely available to female entrepreneurs & 44.50 \\
\hline Information about business regulations is widely available to female entrepreneurs & 27.75 \\
\hline
\end{tabular}


Table 7: Regression results

\begin{tabular}{|c|c|c|c|c|c|c|c|c|c|c|c|c|}
\hline \multirow{3}{*}{$\begin{array}{l}\text { Independent variable } \\
\text { Dependent variables }\end{array}$} & \multicolumn{4}{|c|}{ Panel A: Collateral } & \multicolumn{4}{|c|}{ Panel B: Interest rates } & \multicolumn{4}{|c|}{ Panel C: Personal guarantee } \\
\hline & \multicolumn{2}{|c|}{ Baseline model } & \multicolumn{2}{|c|}{ Model w. interaction } & \multicolumn{2}{|c|}{ Baseline model } & \multicolumn{2}{|c|}{ Model w. interaction } & \multicolumn{2}{|c|}{ Baseline model } & \multicolumn{2}{|c|}{ Model w. interaction } \\
\hline & Logit & Probit & Logit & Probit & Logit & Probit & Logit & Probit & Logit & Probit & Logit & Probit \\
\hline Manufacturing & -0.68 & -0.4 & -0.84 & -0.5 & -0.95 & -0.55 & -1.26 & $-0.68^{*}$ & $-0.85^{*}$ & $-0.52^{*}$ & $-0.95^{*}$ & $-0.58^{* *}$ \\
\hline Trade & $-1.17^{*}$ & $-0.66^{* *}$ & $-1.33^{* *}$ & $-0.75^{* *}$ & -0.28 & -0.22 & -0.42 & -0.28 & $-1.12^{* *}$ & $-0.67^{* * *}$ & $-1.19^{* *}$ & $-0.71^{* * *}$ \\
\hline Ln(Business age) & 0.15 & 0.09 & 0.14 & 0.07 & -0.03 & -0.01 & -0.04 & -0.02 & 0.32 & 0.2 & 0.32 & 0.19 \\
\hline Organizational structure & -0.4 & 0.1 & $-2.28^{*}$ & $-1.32^{*}$ & -0.47 & -0.23 & -0.86 & -0.46 & 0.33 & 0.18 & -0.57 & -0.38 \\
\hline Location & & & & & & & & & 0.14 & 0.08 & -0.12 & -0.08 \\
\hline Age of the entrepreneur: 2 & -0.2 & -0.1 & -0.05 & 0.02 & -0.09 & -0.04 & -0.06 & -0.02 & 0.34 & 0.21 & 0.39 & 0.25 \\
\hline Age of the entrepreneur: 3 & 0.24 & 0.14 & 0.19 & 0.14 & 0.03 & 0.01 & 0.1 & 0.03 & 0.38 & 0.27 & 0.35 & 0.26 \\
\hline Age of the entrepreneur: 4 & & & & & & & & & & & & \\
\hline Education: 2 & 0.88 & 0.49 & -0.04 & -0.04 & -0.6 & -0.34 & -1.17 & $-0.68^{*}$ & 0.46 & 0.3 & -0.05 & -0.02 \\
\hline Education: 3 & 0.82 & 0.41 & -1.38 & -0.86 & -0.9 & -0.46 & -2.25 & -1.28 & -0.46 & -0.27 & -1.65 & -1.02 \\
\hline Education: 4 & $1.77^{*}$ & $1.05^{* *}$ & -1.35 & -0.73 & 0.51 & 0.29 & -1.52 & -0.87 & 0.48 & 0.32 & -1.22 & -0.75 \\
\hline Education: 5 & 1.24 & $0.69^{*}$ & -2.98 & $-1.74^{*}$ & 0.02 & 0.04 & -2.75 & $-1.60^{*}$ & 0.59 & 0.38 & -1.66 & -1.04 \\
\hline
\end{tabular}




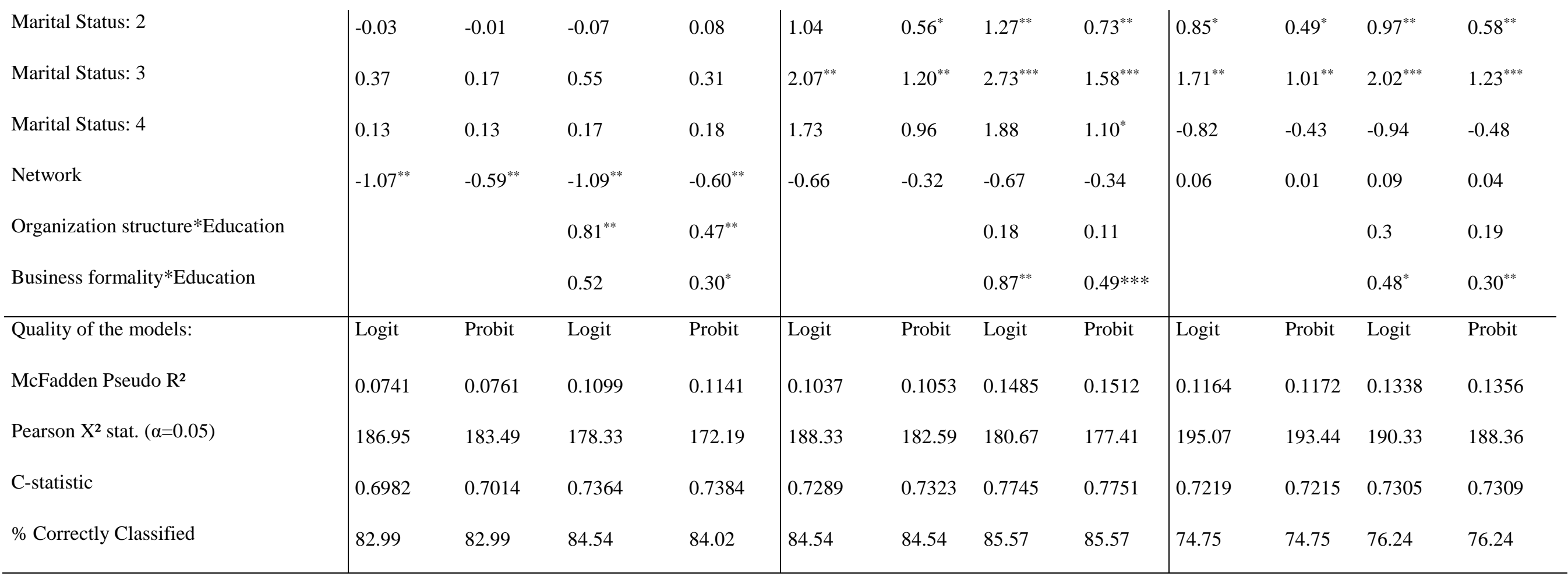

$* p<0.10, * * p<0.05, * * * p<0.01$ 